\title{
Diagnostic Value of Different Biopsy Techniques in Diffuse Lung Intersetitial Diseases
}

\author{
Difüz Interstisyel Akciğer Hastalıklarında Farklı Biyopsi Tekniklerinin Tanısal Değeri
}

Nalan Demir¹, Ayperi Merzi Öztürk¹, Serap Unculu¹, Demet Karnak¹, Oya Kayacan¹

Aim: In most of the diffuse interstitial lung diseases (DILD), bronchoalveolar lavage findings are not specific. When all of the non-invasive methods are insufficient, more invasive methods may be needed for DILD diagnosis. The aim of this study was to evaluate the diagnostic value of bronchoscopic and surgical biopsies in DILD.

Material-Methods: One hundred and forty subjects $(80 \mathrm{~F} / 60 \mathrm{M}$; mean age $=53.25 \pm 16.14$ years) with DILD were evaluated retrospectively. The diagnostic methods and the results of biopsy samples obtained via fiberoptic bronchoscopy and surgery were recorded. Statistical analyses were performed by using the SPSS version 11.0, any $p$ value $<0.05$ was considered significant.

Results: The diagnoses of subjects were idiopathic interstitial pneumonia (IIP) ( $n=76)$, sarcoidosis $(n=37)$ and ILDs due to other reasons $(n=27)$. Totally 110 bronchoscopic biopsies ( 64 transbronchial lung biopsies (TBLB) and 49 bronchial mucosal biopsies (BMB)) were taken. Surgical biopsies were performed in 31 cases (surgical lung biopsy $(n=13)(S L B)$, mediastinoscopy $(n=10)$, extrapulmonary biopsy $(n=8)$ ). The rates of definitive diagnosis for TBLB, BMB, SLB and mediastinoscopy were $26.4 \%$ $(n=17), 16.3 \%(n=8), 92.3 \%(n=12)$ and $100 \%(n=10)$, respectively. In sarcoidosis, TBLB, BMB and SLB were positive in $50 \%(p=0.07), 42.8 \%$ and $75 \%$ of subjects. In IIP cases, these techniques yielded positive results in $18.9 \%, 8.3 \%$ and $100 \%$ of subjects, respectively.

Conclusion: Transbronchial lung biopsy was more successful in the diagnosis of sarcoidosis than other ILDs. In IIP subjects without any definite diagnosis, surgical lung biopsy is needed.

Key Words: Diffuse interstitial lung disease, biopsy, bronchoscopy, surgical lung biopsy

Amaç: Bir çok difüz interstisyel akciğer hastalıklarında (DiAH), bronkoalveolar lavaj bulguları spesifik değildir. Tüm non-invaziv yöntemler yetersiz olduğunda, DiAH tanısı için daha invaziv yöntemler gerekli olabilmektedir. Bu çalıșmanın amacı; DiAH'da bronkoskopik ve cerrahi biyopsilerin tanısal etkinliğini değerlendirmektir.

Yöntem: DiAH olan 140 hasta (80K/60E; ortalama yaș:53.25 \pm 16.14 yıl) retrospektif olarak değerlendirildi. Tanısal yöntemler ve fiberoptik bronkoskopi veya cerrahiyle elde edilen biyopsi örneklerinin sonuçları kaydedildi. İstatistiki analizler SPSS 11,0 versiyonu kullanılarak gerçekleștirildi, $\mathrm{p}<0,05$ anlamlı kabul edildi.

Bulgular: Olguların tanıları idiyopatik interstisyel pnömoni (iip) $(n=76)$, sarkoidoz $(n=37)$ ve diğer nedenlere bağlı IAH ( $n=27)$ idi. Toplam 110 bronkoskopik biyopsi (64 transbronșial akciğer biyopsisi (TBAB) ve 49 bronșial mukozal biyopsi (BMB)) alındı. Cerrahi biyopsiler 31 olguda gerçekleștirildi (cerrahi akciğer biyopsisi $(n=13)(C A B)$, mediastinoskopi $(n=10)$, ekstrapulmoner biyopsi $(n=8))$. Kesin tanı oranları TBAB, BMB,CAB ve mediastinoskopi için sırasıyla $\% 26,4(n=17), \% 16,3(n=8), \% 92,3$ $(n=12)$ ve $\% 100(n=10)$ idi. Sarkoidozda TBAB, BMB ve CAB, \%50 ( $p=0,07), \% 42,8$ ve \%75 olguda pozitifti. iiP olgularında ise bu teknikler sırasıyla \%18.9, \% 8.3 ve $\% 100$ olguda pozitif sonuç verdi.

Sonuç: Transbronșial akciğer biyopsisi diğer interstiyel akciğer hastalıklarına göre sarkoidoz tanısında daha bașarılıdır. Kesin tanı konulamayan iilP olgularında cerrahi akciğer biyopsisi gereklidir.

Anahtar Sözcükler: Difüz interstisyel akciğer hastalıkları, biyopsi, bronkoskopi, cerrahi akciğer biyopsisi

The diffuse interstitial lung diseases (DILD) are a heterogeneous group of more than 150 disorders characterized by inflammation and/or fibrosis of the pulmonary interstitium. The classification of DILD is based on the clinical and radiological features (1). In 2000, the American Thoracic Society (ATS) and the European Respiratory Society (ERS) published the first international consensus as regards the diagnosis and treatment of idiopathic pulmonary fibrosis (IPF) (2). Two 
years later, the classification of interstitial lung diseases (ILD) was modified and the term diffuse parenchymal lung disease (DILD) was introduced $(3,4)$.

On the clinical evaluation of a patient with DILD; a thorough medical history, detailed physical examination, thorax high-resolution computed tomography (HRCT), pulmonary function tests and blood gas analysis are useful for the chest physicians. The diagnostic strategy is based on considerations regarding the dynamic time course (acute, subacute, chronic), the cause (known or unknown), and the context of the disease at presentation (presence of extrapulmonary/systemic disease manifestations) of DILD. The definitive diagnosis and disease severity are fundamental for treatment decisions and to predict prognosis because the prevention, therapy and prognosis differ in each disease $(1,5)$.

Fiberoptic bronchoscopy is widely used in the diagnosis of DILD. When it is inadequate for definitive diagnosis, the diagnostic guidelines on DILD recommend the use of more invasive diagnostic techniques, such as transbronchial lung biopsy (TBLB) and surgical lung biopsy (SLB), when required (3).

Here were repreoent our experience in the diagnosis of DILD. We analyzed the diagnostic value of different biopsy techniques via fiberoptic bronchoscopy or surgery in DILD patients.

\section{MATERIALS AND METHOD}

We conducted a retrospective study including 140 registered patients with DILD diagnosed between the years 2006-2009. Patients were diagnosed according to the new consensus recommendations for DILD published by the ATS and the ERS $(2,3)$. The diagnoses of cases and diagnostic biopsy methods were recorded.
Statistical analysis: Data were analyzed by using SPSS for Windows release 11.0 (SPSS, Chicago, IL). Values were expressed as mean $\pm \mathrm{SD}$. The chisquare test was used to compare categorical variables. T-test was used to compare the mean differences in independent samples. In addition, case summary reports and frequency charts were used to analyze the group variables. All $\mathrm{p}$ values were two-tailed and any $\mathrm{p}$ value $<0.05$ was considered statistically significant.

\section{RESULTS}

One hundred and forty cases with DILD (F/M:80/60) were enrolled in the study. Mean age was 53.25 \pm 16.14 years. The diagnoses of subjects were idiopathic interstitial pneumonia (IIP) $(n=76)(62$ idiopathic pulmonary fibrosis, six cryptogenic organizing pneumonia, four respiratory bronchiolitis-interstitial lung disease, three nonspecific interstitial pneumonia, one lymphocitic interstitial pneumonia), sarcoidosis $(n=37)$, and other ILDs $(n=27)$ (eight connective tissue disease, seven hypersensitivity pneumonitis, two idiopathic pulmonary hemosiderosis, two silicosis, two pulmonary alveolar proteinosis, one drug-induced ILD, one radiation pneumonitis, one amiloidosis, one eosinophilic pneumonia, one vasculitis, one langerhans cell histiocytosis). Flexible bronchoscopy was performed in 110 and 64 transbronchial lung biopsies (TBLB) and 49 bronchial mucosal biopsies (BMB) were obtained. Surgical biopsy was also done in 31 subjects (surgical lung biopsy $(\mathrm{n}=13)$ (SLB), mediastinoscopy $(n=10)$, extrapulmonary biopsy $(\mathrm{n}=8))$.

The patients were subdivided into the groups as IIP, sarcoidosis and other ILDs, and compared according to the biopsy techniques. The clinical diagnoses of 64 cases who underwent TBLB were sarcoidosis $(n=14)$, IIP $(n=37)$ and other ILD $(n=13)$. Positive histopathological findings were obtained in 17 of 64 TBLB (Sarcoidosis $\mathrm{n}=7 ; 50 \%$, IIP $\mathrm{n}=7$; $18.9 \%$ and other ILD $n=3 ; 23.1 \%$ ). TBLB was positive in half of sarcoidosis patients, and it was not diagnostic in most of the cases with IIP and other ILDs. However, this difference was not significant statistically $(\mathrm{p}=0.07)$.

Forty-nine bronchial mucosal biopsies were performed in 24 IIP, 14 sarcoidosis and 11 other ILD patients. It was positive in only eight cases (six sarcoidosis and two IIP), while it was negative in other ILD cases. Bronchial mucosal biopsises were negative in most of cases with ILD and this was statistically significant $(\mathrm{p}=0.005)$ (Fig.1).

Surgical lung biopsy (SLB) was performed in 13 cases of study subjects. As expected, definitive diagnosis was confirmed by SLB in $92.3 \%$ of subjects (six IIP, three sarcoidosis, three other ILD), except one case with sarcoidosis.

Mediastinoscopy was performed in 10 patients. All samples obtained by mediastinoscopy were positive in one IIP and nine sarcoidosis cases.

Extrapulmonary biopsies were also done in eight subjects, with seven positive results (six sarcoidosis, one other ILD, 87.5\%)(Fig.2).

The diagnostic accuracies of TBLB, BMB, SLB and mediastinoscopy were $26.4 \%, \quad 16.3 \%, 92.3 \%$ and $100 \%$, respectively.

In cases with Sarcoidosis, TBLB, BMB and SLB were positive in $50 \%, 42.8 \%$ and $75 \%$ of subjects. In IIP cases, these techniques were positive in $18.9 \%, 8.3 \%$ and $100 \%$ of subjects, respectively (Table 1). Bronchoscopic biopsy techniques were more diagnostic in cases with sarcoidosis than IIP $(p=0.002)$ (Table 2). 


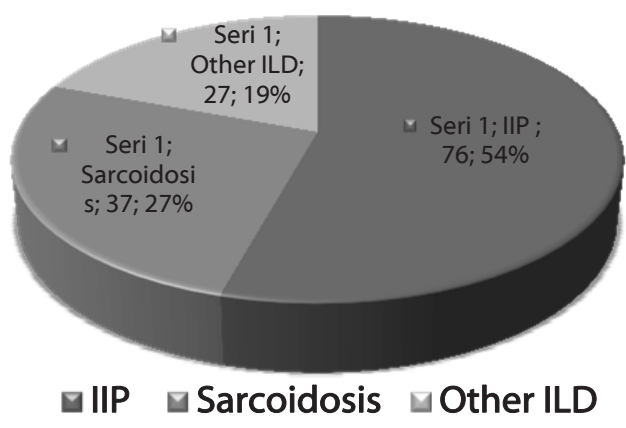

Figure 1: The diagnoses of study subjects

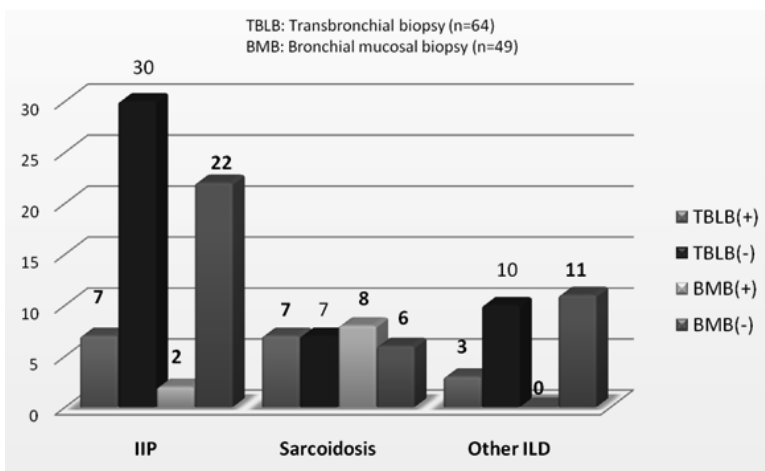

Figure 2: The diagnostic rate of bronchoscopic biopsy techniques in study subjects (+) : diagnostic, (-): non-diagnostic

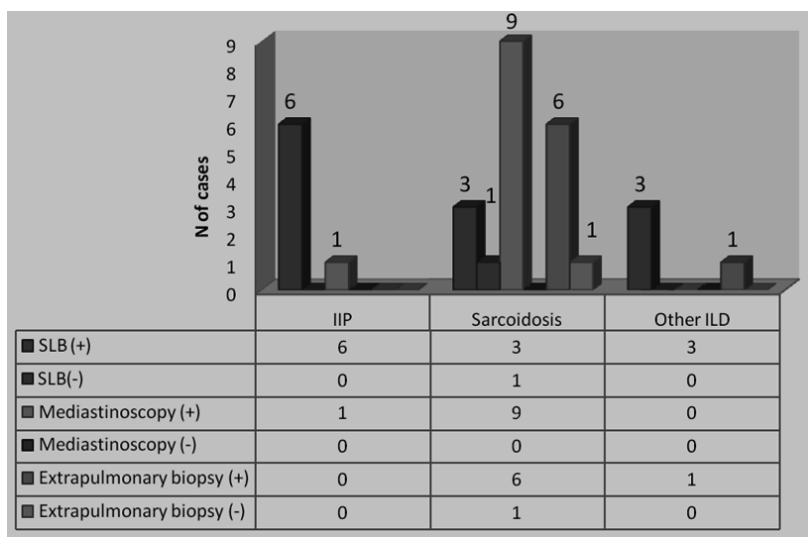

Figure 3: The diagnostic rate of surgical biopsy techniques in study subjects

Table 1: The biopsy techniques and rate of diagnosis in DILD subjects

\begin{tabular}{|l|l|l|l|l|}
\hline & IIP \% (positivity/n) & Sarcoidosis \% (positivity/n) & Other ILD \% (positivity/n) & DILD \% (positivity/n) \\
\hline TBLB & $18.91(7 / 37)$ & $50(7 / 14)$ & $23.07(3 / 13)$ & $26.56(17 / 69)$ \\
\hline BMB & $8.33(2 / 24)$ & $42.85(6 / 14)$ & $0(0 / 11)$ & $16.32(8 / 49)$ \\
\hline SLB & $100(6 / 6)$ & $75(3 / 4)$ & $100(3 / 3)$ & $92.30(12 / 13)$ \\
\hline Mediastinoscopy & $100(1 / 1)$ & $100(9 / 9)$ & 0 & $100(10 / 10)$ \\
\hline Extrapulmonary biopsy & 0 & $85.71(6 / 7)$ & $100(1 / 1)$ & $87.50(7 / 8)$ \\
\hline
\end{tabular}

Table 2: The comparison of sarcoidosis and IIPsubjects according to the diagnosticrate of bronchoscopic and surgical biopsies.

\begin{tabular}{|l|l|l|l|}
\hline & IIP \% (positivity/n) & Sarcoidosis \% (positivity/n) & P value \\
\hline Bronchoscopic biopsy & $17.4(8 / 46)$ & $56.5(13 / 23)$ & 0.002 \\
\hline Surgical biopsy & $100(7 / 7)$ & $90(18 / 20)$ & 1.0 \\
\hline
\end{tabular}

\section{DISCUSSION}

The diagnosis of diffuse interstitial lung diseases is often a challenge for the physicians. Thus, making an accurate diagnosis of a specific type of DILD requires a careful approach including a complete patient history, physical examination, appropriate laboratory testing, and thoracic imaging. For definitive diagnosis, different biopsy techniques can be used to obtain appropriate tissue. The selection of biopsy type should be done on basis of scientific rationale, stage of disease and pattern, besides traditional approaches. Additionally, appropriate clinical information should be provided to the pathologist (6). In this retrospective study, we reviewed a series of 140 registered patients with DILD. We observed a high proportion of TBLB performed for the diagnostic work-up of DILD.

Bronchoscopic biopsies are frequently needed to establish definitive diagnosis of DILD along with cell counts on bronchoalveolar lavage fluid. TBLB through the flexible bronchoscopy is used widely to confirm the tissue diagnosis of DILD. Its diagnostic accuracy ranges between $20-55 \%$ in DILD $(7,8)$. The definitive diagnosis rate can increase up to $55.3 \%$ by combining pathological findings of TBLB with clinical and radiological features (9). Transbronchial lung biopsy is useful to establish tissue diagnoses in certain diffuse parenchymal lung diseases with specific recognizable histologic 
patterns such as sarcoidosis or eosinophilic granuloma, but it is less useful for disorders such as interstitial pulmonary fibrosis (10). In this study, the diagnostic accuracy of TBLB was $26.4 \%$ and it was shown to be an efficient diagnostic method especially in sarcoidosis as shown in previous studies (11).

Bronchial mucosal biopsies are also frequently used for DILD diagnosis. However, diagnostic rate is low, although it is a safe method for DILD patients (12). We observed that the most bronchial mucosal biopsies were inadequate for histopathological diagnosis in patients with DILD.

Although TBLB is useful in the diagnosis of many diffuse lung diseases as mentioned above, it is not a replacement for surgical lung biopsy because of small pieces of tissue obtained via TBLB (13). When nonspecific findings by TBLB do not correlate with the clinical picture,

\section{REFERENCES}

1. Behr J. Approach to the diagnosis of interstitial lung disease. Clin Chest Med. 2012; 33(1):1-10.

2. American Thoracic Society. Idiopathic pulmonary fibrosis: diagnosis and treatment. International consensus statement. American Thoracic Society (ATS), and the European Respiratory Society (ERS). Am J Respir Crit Care Med. 2000; 161(2 Pt 1):646-664.

3. American Thoracic Society/European Respiratory Society International Multidisciplinary Consensus Classification of the Idiopathic Interstitial Pneumonias. This joint statement of the American Thoracic Society (ATS), and the European Respiratory Society (ERS) was adopted by the ATS board of directors, June 2001 and by the ERS Executive Committee, June 2001. American Thoracic Society; European Respiratory Society. Am J Respir Crit Care Med. 2002 15; 165(2):277-304.

4. Spectrum of fibrosing diffuse parenchymal lung disease. Morgenthau AS, Padilla ML. Mt Sinai J Med. 2009; 76:2-23. invasive procedures are required and SLB should be performed (5).

At present, SLB has the greatest overall diagnostic sensitivity (90-95\%) for diffuse interstitial lung diseases. However, SLB may be associated with a significant risk of morbidity and mortality, although there are good safety records in previous studies. The overall 30-day mortality for SLB was $4.3 \%$ versus $2.1 \%$ for video-assisted thorascopic surgery (VATS) biopsy, and non-lethal complications seem to occur more frequently with SLB (18.1\%) vs. VATS $(9.6 \%)$ procedures. In practice, when sufficient doubt exists about diagnosis, surgical lung biopsy must be done $(14,15)$. The optimal selection of the cases to minimize the mortality and to optimize the diagnostic performance is essential.

When surgery

is needed, mediastinoscopy is the first step in cases of suspected stage I or II sarcoidosis (16). In this study, the accurate diagnosis by mediastinoscopy was obtained in all subjects with 1 IIP and 9 sarcoidosis.

The most important factor in the diagnostic accuracy of different biopsy techniques is the quality and size of the samples. Additionally, time course and localization of disease in DILD also play role in diagnosis. Thus, the selection of biopsy techniques in the diagnosis of DILD patients is critical for the chest physicians.

In summary, this study describes our experience applied in routine practice for diffuse lung disease. We observed that bronchoscopic biopsy techniques especcially transbronchial lung biopsy were more successful in the diagnosis of patients with sarcoidosis than IIP and other ILDs. Although radiological evaluation is useful for the diagnosis of most IIP cases, surgical lung biopsy should be performed in selected patients without any definite diagnosis.
5. Kayacan O. Approach of diffuse interstitial lung diseases. Tuberk Toraks. 2004; 52(3):285-299.

6. Popper HH. Which biopsies in diffuse infiltrative lung diseases and when are these necessary? Monaldi Arch Chest Dis. 200; 56(5):446-452.

7. Zsiray M, Appel J, Lantos A. Transbronchial biopsy in diffuse infiltrative lung diseases. Orv Hetil. 1999 30; 140(22):1239-1243.

8. Shi JH, Xu WB, Liu HR, et al. The diagnostic value of transbronchial lung biopsy in diffuse parenchymal lung diseases. Zhonghua Jie $\mathrm{He} \mathrm{He} \mathrm{Hu} \mathrm{Xi} \mathrm{Za}$ Zhi. 2008; 31:22-25.

9. Kulshrestha R, Menon BK, Rajkumar, Vijayan VK. Role of a pattern-based approach in interpretation of transbronchoscopic lung biopsy and its clinical implications. Indian J Chest Dis Allied Sci. 2012; 54(1):9-17.

10. Kvale PA. Bronchoscopic biopsies and bronchoalveolar lavage. Chest Surg Clin N Am. 1996; 6(2):205-222.
11. Szlubowski A, Soja J, Kuzdzał J, et al. Transbronchial lung biopsy as a diagnostic method of diffuse pulmonary diseases. Pneumonol Alergol Pol. 2004; 72(5-6):165-169.

12. Danila E, Zurauskas E, Loskutoviene G, et al. Significance of bronchoscopic lung biopsy in clinical practice. Adv Med Sci. 2008; 53(1):11-16

13. Ibrahim AS, Allangawi MH, Sattar HA, Mobyed HS, Almohammed AA. Indications, diagnostic yields and complications of transbronchial biopsy over 5 years in the State of Qatar. Saudi Med J. 2005; 26(4):641-645.

14. Glaspole IN(1), Wells AU, du Bois RM. Lung biopsy in diffuse parenchymal lung disease. Monaldi Arch Chest Dis. 2001; 56(3):225-232.

15. Nguyen W, Meyer KC. Surgical lung biopsy for the diagnosis of interstitial lung disease: a review of the literature and recommendations for optimizing safety and efficacy. Sarcoidosis Vasc Diffuse Lung Dis. 2013; 30(1):3-16.

16. Rizzato G. The role of thoracic surgery in diagnosing interstitial lung disease. Curr Opin Pulm Med. 1999; 5(5):284286. 